\title{
Benthic metabolism in two turbid dryland rivers
}

Christine S. Fellows, Stuart E. Bunn, Fran Sheldon and Nerida J. Beard

with 4 Tables and 7 Figures

Australian Rivers Institute, Griffith School of Environment, Griffith University, Nathan, Queensland, 4111, Australia

c.fellows@griffith.edu.au, +61 (0)7 37353840

Running head: Dryland river benthic metabolism

Keywords: gross primary production, respiration, waterhole, desert river, light limitation 
Summary

1. Australian dryland rivers have the most variable discharge of any rivers world-wide, and are characterised by extended periods of no flow during which aquatic habitat contracts into isolated waterholes. Despite naturally high turbidity, benthic primary production is known to be the main source of carbon to waterhole food webs.

2. We quantified rates of benthic gross primary production (GPP) and respiration in waterholes from two Australian dryland rivers, the Cooper Creek and the Warrego River, and explored controls on these processes. Both rivers have similar variable hydrology and high levels of turbidity (photic depths $<0.4 \mathrm{~m}$ ), but fish abundance in Cooper Creek is 10 times that of the Warrego River, suggesting an underlying difference in primary production.

3. Benthic metabolism, nutrient concentrations and light penetration were measured immediately following flow (post-flow) and after at least 2 months of no flow (dry) in 15 waterholes from each river. Light was the major control on benthic GPP in both rivers, with a stronger influence during immediate post-flow compared to after extended dry conditions.

4. Cooper Creek generally had higher rates of GPP and a more autotrophic benthic zone than the Warrego River. As a result, the positive relationship predicted between fish abundance and GPP was generally observed at a broad catchment scale.

5. Although flow variability in dryland rivers is extreme compared to other rivers worldwide, cycles of expansion and contraction of aquatic habitat in these two rivers were associated with a shift in the importance of regional scale (subcatchments contributing to river flow) versus local scale (waterhole morphology) influences on ecosystem functioning, similar to floodplain rivers in tropical and temperate regions. 


\section{Introduction}

Dryland rivers are an important subset of the world's freshwaters, draining around half of the global land surface (Davies et al., 1994). Flowing entirely or partly through regions with less than $500 \mathrm{~mm}$ of annual rainfall (Kingsford \& Thompson, 2006), these rivers are less well studied than their counterparts in more humid climates, in part due to the generally low population densities of dryland catchments (Davies et al., 1994). Dryland rivers are particularly well represented in Australia, with $75 \%$ of the continent's land area being classified as semi-arid or arid (Davies et al., 1994). High variability in discharge is typical of dryland rivers, but Australian dryland rivers represent some of the most variable hydrographs of rivers world-wide, encompassing massive floods as well as extended periods of zero discharge (Puckridge et al., 1998; Young \& Kingsford, 2006).

Dryland floodplain rivers in Australia are described as having a 'boom and bust' ecology, with high primary and secondary production associated with floodplain inundation, followed by ecosystem retraction as waters recede (Kingsford \& Thomas, 1995; Walker, Sheldon \& Puckridge, 1995; Kingsford, Curtin \& Porter, 1999; Puckridge, Walker \& Costelloe, 2000). While a focus has often been placed on the spectacular population dynamics of plants and animals associated with the 'boom' phase, processes that occur during the 'bust' phase may be equally important as they influence survival between floods, especially for fully aquatic organisms. Aquatic habitats that persist through the dry phase, such as floodplain lakes and lagoons and in-channel pools, serve as refugia for aquatic organisms. An important and widely distributed type of refugium in Australian dryland rivers is waterholes -- deep channel segments associated with points of flow convergence (Knighton \& Nanson, 1994). The extremely variable hydrology of these rivers (Puckridge et al., 1998) interacts with local geomorphology to create spatially and temporally dynamic systems. Floods and in-channel flow serve to connect waterholes, and periods of no flow 
result in disconnection, where waterholes become discrete lentic waterbodies. A unique feature of these rivers is permanent high mineral turbidity due to fine clays in suspension, even under no-flow conditions (Bailey, 2001; Sheldon, Boulton \& Puckridge, 2002; Bunn, Davies \& Winning, 2003).

While desert rivers often have high levels of primary production due to high irradiance (Minshall, 1978; Fisher et al., 1982; Mulholland et al., 2001), autochthonous production would be expected to be low and light limited in dryland rivers with turbid waters. In particular, benthic production would not be expected to be quantitatively important to overall carbon availability or to aquatic foodwebs due to limited light penetration (Vadeboncoeur \& Steinman, 2002). Nevertheless, benthic algae have been shown to be the major source of energy supporting waterhole food webs in Cooper Creek, an Australian dryland river, during no-flow conditions (Bunn et al., 2003). Stable isotope analysis indicated that benthic algae made significant contributions to the biomass carbon of invertebrates, fish and turtles in these waterholes. An increased role for benthic production during periods of no flow is consistent with a proposed model for carbon dynamics in turbid dryland rivers in which the shallow peripheral photic zone is relatively stable under conditions of slowly changing water levels, resulting in an increase in autochthonous production (Walker et al., 1995; Bunn et al., 2006b). Because benthic algae are an important basal carbon resource, understanding controls on benthic production is crucial to characterising processes that sustain higher trophic levels in refugia during the time between flows.

Previous work investigating fish dynamics in Cooper Creek and the adjacent Warrego River suggests that fish may become food limited during no-flow conditions (Arthington et al., 2005; Balcombe et al., 2006). Fish abundance is closely linked to recent flow conditions, with floods supporting reproduction and recruitment that lead to very high abundances 
(Balcombe et al., 2005). Intermediate abundances follow in-channel flows, while low abundances are associated with the subsequent recession and development of discrete waterholes (Arthington et al., 2005; Balcombe et al., 2006). Despite similarities in hydrology, high levels of inorganic turbidity, and patterns of fish dynamics, fish abundance in Cooper Creek waterholes is nearly 10 times greater than that in Warrego River waterholes, even after extended periods of no flow (Arthington et al., 2005; Balcombe et al., 2006). This suggests potential differences between the catchments in fish production and underlying processes contributing to this production.

The observed importance of benthic algae to food webs in dryland river waterholes under no-flow conditions (Bunn et al., 2003) suggests that rates of benthic primary production should be linked to waterhole secondary production and maintenance of aquatic biota between floods. Along these lines, differences in fish abundance between the Cooper Creek and Warrego River during no-flow periods may be related to differences in benthic production. The aims of this study were to 1) compare rates of benthic metabolism between the Cooper Creek and Warrego River, 2) identify factors influencing rates of benthic metabolism, and 3) investigate links between benthic primary production and fish abundance. To explore the influence of time since flow, waterholes in both catchments were sampled under conditions immediately following flow and after extended periods of no flow.

\section{Methods}

\section{$\underline{\text { Study Sites }}$}

Cooper Creek is a large catchment $\left(306,000 \mathrm{~km}^{2}\right)$, within the Lake Eyre basin of Australia (Figure 1). The Warrego River has a smaller catchment area of 78,400 $\mathrm{km}^{2}$ and is located in the Upper Murray-Darling Basin. Both catchments are characterised by low gradients, extensive floodplains and numerous waterholes. The region has highly variable 
annual rainfall, and both rivers have extremely variable flow, even in comparison to other dryland rivers (Puckridge et al., 1998; Young \& Kingsford, 2006). Long periods of no flow are typical (Figure 2). Waterholes in the catchments vary in their degree of permanence, but all study sites had water present for the 2 year duration of the study (April 2001 to May 2003). More details about the catchments can be found in McGregor et al. (2006), Bunn et al. (2006a) and Balcombe et al. (2006).

Waterholes were selected in each river to represent the natural range of size, shape, connectivity, and water permanence. Three or four waterholes were chosen at four reaches within each river, for a total of 15 waterholes per river (Figure 1; Table 1). The full set of waterholes in each catchment was sampled on two occasions with contrasting hydrologic conditions_-dry (Spring) and post-flow (Autumn) (Table 2). To determine if observed patterns were consistent over time, a subset of four waterholes in each catchment was sampled an additional two times (dry and post-flow). Typically, post-flow sampling was conducted 2-3 months after a channel flow event or flood, at the time when waterholes were just becoming disconnected (in each case, there was still measurable but very low flow at the relevant gauging stations) (Figure 2). Dry sampling was conducted after an extended period of no flow (2 - 6 months) and 8 - 11 months after a channel flow event or flood.

\section{Benthic metabolism}

Benthic gross primary production (GPP) and respiration (R) in the photic zone were measured by monitoring changes in DO concentrations in enclosed transparent chambers (Bott et al., 1978; Fellows et al., 2006; Fellows et al., 2007). Dome-shaped perspex chambers (Fellows et al. 2007; diameter $=0.295 \mathrm{~m}$, total height $=0.25 \mathrm{~m}$ ) were pushed into the littoral zone sediment to a depth of approximately $10 \mathrm{~cm}$, resulting in a volume of $5 \mathrm{~L}$ and a surface area of $0.068 \mathrm{~m}^{2}$ for the enclosed substrate. Actual depth of insertion was measured 
and used to calculate water volume for each chamber. Chambers were inserted so that the top of the dome was just submerged, and the water depth at the center of the chamber was approximately $0.15 \mathrm{~m}$. Each chamber had a dissolved oxygen (DO) sensor (YSI 5739, YSI Incorporated, Ohio, USA) attached to a data-logger (TPS 601, TPS Pty Ltd, Queensland, Australia), which recorded DO and temperature at 10-minute intervals for $24 \mathrm{~h}$. The temperature inside the benthic chambers was never more than $3^{\circ} \mathrm{C}$ greater than the ambient water column temperature and generally remained within $1^{\circ} \mathrm{C}$. A pump recirculated water through the chamber to ensure flow saturation across the membrane of the oxygen sensor. The resulting water movement in the chambers was of a similar magnitude to that typically observed in the littoral zone due to wave action. Four chambers were deployed at each waterhole based on previous work that suggested that within-waterhole littoral zone variation was relatively small (P.M. Davies, unpubl. data).

Changes in chamber DO concentrations during the night were used to calculate R, while changes during the day were used to calculate GPP. To calculate respiration, the mean rate of change was calculated for a period during the night over which the change in DO concentration was linear with time, and included at least 6 h (Fellows et al., 2006; Fellows et al., 2007). Daily respiration was calculated by assuming the rate was constant over $24 \mathrm{~h}$. GPP was calculated for each 10 minute interval during daylight hours as the sum of the DO produced plus the DO consumed by respiration based on the night-time respiration rate (Fellows et al., 2006; Fellows et al., 2007). The intervals were summed to determine total GPP for the $24 \mathrm{~h}$ period. The GPP/R ratio was also calculated based on a $24 \mathrm{~h}$ period. Changes in DO concentrations over time (mg $\left.\mathrm{O}_{2} \mathrm{~L}^{-1} \mathrm{~h}^{-1}\right)$ were multiplied by chamber volume and divided by substrate surface area to obtain values in units of $\mathrm{mg}_{2} \mathrm{~m}^{-2} \mathrm{~h}^{-1}$. These rates were converted to units of carbon assuming that one mole of carbon is equivalent of one mole of $\mathrm{O}_{2}$ for both respiration and photosynthesis (Lambert, 1984; Bender et al., 1987). Rates of 
benthic metabolism and GPP/R are presented as the mean of four replicates, except as noted for cases where interference by livestock or equipment failure resulted in fewer replicates.

\section{$\underline{\text { Water chemistry and other supporting data }}$}

The water column was characterised with a combination of in situ measurements and samples collected for later analysis of water chemistry. Depth profiles of irradiance were obtained using a Licor quantum sensor (LI-192SA, LI-COR Biosciences, Nebraska, USA) and were used to calculate light attenuation coefficients $\left(\mathrm{K}_{\mathrm{d}}\right)$. Photic zone depths were calculated as the depth at which 1\% of incident light remained (Wetzel \& Likens, 1991). Ambient water temperature at $0.2 \mathrm{~m}$ below the surface was recorded at 10 minute intervals for $24 \mathrm{~h}$ using a data-logger (TPS 601) and mean values were calculated for the $24 \mathrm{~h}$ period. A $10 \mathrm{~L}$ depth-integrated sample of the water column was collected and two sub-samples stored for water chemistry analysis in the laboratory. One sub-sample was kept at room temperature and analysed for electrical conductivity. The other sub-sample was frozen and analysed for total phosphorus (TP) and total nitrogen (TN). A portion the frozen sub-sample was filtered in the lab after thawing and analysed for nitrate-N. Standard analysis methods were used and more details can be found in Marshall et al. (2006).

\section{$\underline{\text { Data analysis }}$}

Distributional properties of the data were checked to identify outliers and the need to transform the data for subsequent statistical analyses. Distributional properties were improved by log transformation for all variables except the GPP/R ratio, for which square root transformation was more successful. Mean waterhole values were used in analyses for measures for which there were two or more replicates per site (GPP, R, GPP/R). Data were analysed using the SAS system for Windows, V 8.0 (SAS Institute, 1999) with the exception 
of multivariate analyses which were performed using PRIMER ${ }^{\mathrm{TM}}$ V.5 (Clarke \& Gorley, 2001).

While the chosen waterholes were geographically grouped within reaches in each river, comparing the two rivers was a primary focus of the study. One-way Analysis of Variance (ANOVA) was conducted to determine if benthic metabolism differed between reaches within a river or if it was appropriate to treat the waterholes as replicates within the river without being nested in reaches. Two full dry trips (Cooper Creek September 01 and Warrego River October 01) were analysed with river and reach within river using nested oneway ANOVA for log GPP, $\log \mathrm{R}$, and the square root of GPP/R. River was significant at a level of 0.01 or greater, while $p$ values for reach within river exceeded 0.05 with the exception of $\log$ GPP, with a value of 0.037 . With the removal of one waterhole which had extremely turbid water (photic zone $3 \mathrm{~cm}$; Noorama waterhole, Warrego River), reach within river was not significant, with a $p$ value of 0.18 . In further analyses, waterholes were treated as replicates within each river.

One of the aims of this study was to identify variables influencing rates of benthic metabolism. While univariate analysis, such as ANOVA, would quantitatively suggest differences in variables between rivers and trips, we wished to explore the collective influence of the range of measured variables on GPP and perhaps identify the main drivers. Principal Components Analysis (PCA) was therefore used to explore differences between rivers and among trips and to identify those variables contributing to observed differences. Principal components with eigenvalues greater than 1 were considered significant. Significance was not determined for loadings on the components (for example, using bootstrapping, see Peres-Neto, Jackson \& Somers, 2003), with component loadings greater than 0.5 considered as influencing each principal component. Metabolism values (GPP and R) and water quality variables that were selected a priori for their potential influence on benthic 
metabolism (TN, TP, nitrate-N, photic zone depth, electrical conductance) were analysed for all waterholes from all trips. Initial analysis determined that one waterhole was extremely influential in the PCA due to an extremely low value of photic zone depth (the same waterhole omitted from the ANOVAs -- Noorama, Warrego River, Oct 2001), and the analyses were subsequently conducted with this waterhole excluded. Mean $( \pm$ SE) values of PC1 and PC2 were calculated for each river (all waterholes, all trips, $n=38$ per river), each full trip (14 or 15 waterholes per river, 4 trips total), and all trips for the subset of four waterholes in each (4 waterholes per river, 8 trips total).

Bivariate plots of trip mean values for metabolism and water chemistry were used to explore differences between rivers and among trips in more detail. Plots were constructed for GPP versus photic zone depth; R versus GPP; and TP versus TN for the full set of waterholes (4 trips) and the subset of waterholes (8 trips). Plots of R versus GPP were also compared to the 1:1 line to determine if the benthic zone was autotrophic or heterotrophic. Linear regression was used to explore relationships between GPP and potentially related variables (TN, TP, nitrate-N, photic zone depth) and between R and GPP. Regression analyses were performed on waterhole means for all trips to both rivers combined $(n=76)$, each river separately $(n=38)$, and each full trip $(n=15)$. Values from the four trips to only the subsets of four waterholes were included in the all-trips and whole-river analyses, but were not analysed as individual trips because there were only four points per trip. Bivariate plots and linear regression also were used to examine links between fish abundance (catch per unit effort [CPUE]) and GPP as described above. Fish abundance and waterhole morphology data were measured during the same trips and values are taken from Arthington et al. (2005) and Balcombe et al. (2006). 


\section{Results}

\section{$\underline{\text { Multivariate exploration }}$}

PCA suggested the two rivers were distinct in multivariate space, especially for the trips conducted under dry conditions. The first two principal components were significant (eigenvalues greater than one) and together explained 76\% of the variation across waterholes (Table 3). The third component was non-significant (eigenvalue $=0.65$ ) and only added an additional 9\%. The three nutrient variables explained the majority of the variation in PC1, with coefficients of 0.5 or greater in magnitude (Table 3). PC2 correlated with benthic metabolism and light penetration, with GPP, R, and photic zone depth all having coefficients of 0.5 or greater. Electrical conductance was the only variable that had a large coefficient for PC3. The two rivers separated distinctly using mean values for PC1 and PC2, with the Warrego River higher on both axes than Cooper Creek (Figure 3A).

Looking at the four full trips, the two rivers separated on PC2 but overlapped on PC1 (Figure 3B). The two dry trips were more separated than the two post-flow trips, suggesting that the rivers were more similar post-flow than after extended dry periods. Similar patterns were observed when considering the trips to waterhole subsets ( 4 waterholes per river, 8 trips total). The Warrego trips were again separated from the Cooper trips with higher values on PC2, with the exception of the second Warrego post-flow trip (April 02; Figure 3C). This Warrego post-flow trip was lower on PC2, grouping it with the Cooper trips. The waterhole subsets also suggested a separation between dry and post-flow trips along PC1, with postflow trips having higher values.

\section{Bivariate exploration}

Similar to the results of the multivariate analysis, bivariate plots for all three pairs of investigated variables suggested that differences between rivers were greater under dry 
conditions compared to post-flow (Figure 4). Trends seen in the four full trips were generally supported by the additional trips to waterhole subsets, as values for the second set of trips were very similar to those of the first (Figures 4B, D and F). The second Warrego post-flow trip was an exception, having higher values for benthic metabolism and photic zone depth. The large difference between the two Warrego post-flow trips suggested a greater degree of year to year variation in post-flow compared to dry conditions.

In general, Cooper Creek had higher rates of GPP and a more autotrophic benthic zone (GPP > R) than the Warrego River, but rates of $\mathrm{R}$ were more similar between rivers (Figures 4A and B). Cooper Creek under dry conditions had the greatest values of GPP and was the most autotrophic. In contrast, the Warrego River under both dry and post-flow conditions had values of benthic GPP that were less than $0.2 \mathrm{~g} \mathrm{C} \mathrm{m}^{-2} \mathrm{~d}^{-1}$ and were heterotrophic ( $>$ GPP). The only exception was the second post-flow trip (May 03), which had a value of $0.31 \pm 0.07 \mathrm{~g} \mathrm{C} \mathrm{m}^{-2} \mathrm{~d}^{-1}$ and fell on the $1: 1$ line. This second post-flow Warrego trip grouped with Cooper Creek under post-flow conditions, falling on the 1:1 line and with values of GPP intermediate between Cooper Creek dry and the other Warrego River trips.

There was considerable overlap in photic depth values for the two rivers, but the observed higher GPP values in Cooper Creek suggested differences between rivers in the relationship between photic depth and GPP, especially for dry conditions (Figures 4C and D). The dry trips for each river had lower values of photic depth than the corresponding wet trips, but the rivers had different responses in GPP. Despite lower values of photic depth, Cooper Creek GPP was greater for dry trips compared to post-flow trips. For the two full Warrego trips, GPP was low and similar, despite a difference of $6.5 \mathrm{~cm}$ in photic zone depths. Only the second post-flow Warrego trip fit the expected pattern of higher rates of GPP with greater photic depths (Figure 4D). This trip grouped with the post-flow Cooper trips, where photic depth was higher and GPP was moderate. 
Nutrient concentrations were low and similar for both rivers during the post-flow trips, but were higher under dry conditions in both rivers (Figures 4E and F). Variation also was greater during dry trips than during post-flow trips. These trends were supported by the four full trips (Figure 4E) as well as the subsets of four waterholes across eight trips (Figure 4F). Across all trips, mean nutrient concentrations were relatively high. Mean values of TP ranged from $0.21 \pm 0.04 \mathrm{mg} \mathrm{L}^{-1}$ to $0.83 \pm 0.29 \mathrm{mg} \mathrm{L}^{-1}$. Concentrations of TN were higher, ranging from $0.75 \pm 0.05 \mathrm{mg} \mathrm{L}^{-1}$ to $3.21 \pm 0.61 \mathrm{mg} \mathrm{L}^{-1}$. Nitrate-N comprised from $24 \%$ to $53 \%$ of TN, with values ranging from $0.20 \pm 0.02 \mathrm{mg} \mathrm{L}^{-1}$ to $1.70 \pm 0.47 \mathrm{mg} \mathrm{L}^{-1}$. Patterns in nitrate-N generally followed those for TN, so plots are shown only for TN.

\section{$\underline{\text { Factors influencing benthic metabolism }}$}

Rates of GPP explained a substantial amount of the variation in $\mathrm{R}$, but the relationships were stronger for Cooper Creek compared to the Warrego River (Table 4). The relationship was not significant for the two full Warrego trips, but it was highly significant for both the post-flow and dry full Cooper trips $\left(\mathrm{r}^{2}=0.78, p<0.0001\right.$ and $\mathrm{r}^{2}=0.68, \mathrm{p}=$ 0.0001, respectively). A tight link between benthic GPP and R was suggested by the high $r^{2}$ values for these two trips.

The relationship between GPP and photic zone depth was positive and significant for all relationships tested (all trips, each river separately, each full spatial trip separately), but the strengths of the relationships varied (Table 4). The Cooper Creek and Warrego River post-flow trips had the greatest values of $r^{2}$ of the relationships tested, with photic zone depth explaining 68 and 64\% of the variation in GPP, respectively (Figure 5). The dry trips but had lower $r^{2}$ values of 0.36 for Cooper Creek and 0.40 for the Warrego River.

Overlaid on the general trend of increasing GPP with increasing photic zone depth, hydrology had an additional influence on GPP. For the two full Cooper Creek trips, the 
waterhole values of GPP during dry conditions were generally higher than during post-flow conditions for similar values of photic zone depth (Figure 5A). This pattern was also observed to a lesser extent for the two full Warrego trips (Figure 5B).

In general, relationships between GPP and nutrient concentrations were not significant (Table 4). However, values of GPP increased with decreasing nutrient concentrations in cases where the relationships were significant ( $\mathrm{TN}$ - Warrego dry; $\mathrm{TP}$ Warrego all trips, Cooper post-flow, Warrego dry; nitrate-N-Warrego post-flow).

\section{Links between fish abundance and GPP}

The general pattern of higher GPP in Cooper Creek waterholes compared to those in the Warrego River matched the pattern of fish catches (Figure 6). When all trips to both rivers were considered, CPUE was significantly positively related to benthic GPP $\left(r^{2}=0.27\right.$, $p<0.0001$ ) (Table 4, Figure 7A). However, at the level of river or individual trips the relationship between CPUE and GPP was not always significant. The relationship was not significant for Cooper Creek, while it was for the Warrego River (Table 4). The relationship was significant for the full post-flow trip for each river (Figures $7 \mathrm{~B}$ and C), but was not significant for the full trip during the dry period for either river.

\section{Discussion}

Conceptual model of dryland river functioning

Light appears to be the major factor limiting benthic primary production in these dryland systems given the generally high nutrient concentrations and stronger relationships between GPP and photic zone depth than with nutrients. Light penetration exerted a stronger control on benthic production under recent post-flow conditions compared to dry conditions, indicating a shift in the relative importance of this factor with changes in hydrology. This 
shift was seen across both rivers, but differences between rivers in the magnitude of benthic metabolism for both dry and post-flow conditions suggest that the rivers differ in factors responsible for the weaker relationships between light and production during the dry period. Using data from the present study and theoretical predictions made by Walker et al. (1995) and Bunn et al. (2006b), a general conceptual model of dryland river benthic production and the influence of hydrology is outlined below. Specific differences between the two rivers are used to look at factors influencing benthic primary production in more detail.

Flood/channel flow event-The filling and connecting of waterholes via flood or channel flows resets the physical and chemical template for benthic algal production by rapidly submerging the previous benthic photic zone (Bunn et al., 2006b) and changing water turbidity and nutrient concentrations. Water physico-chemical characteristics can be influenced at a regional scale by the relative contributions of different sub-catchments and the timing and magnitude of flow pulses (Hart et al., 1995; Puckridge et al., 2000). Floods and channel flows generally have higher turbidity than low and no-flow conditions (e.g. Burford et al., in press). While flow is occurring and water levels are fluctuating, benthic algal production is predicted to be low (Bunn et al., 2006b). Waterhole to waterhole variability is also predicted to be low, since the level of connectivity is at a maximum (Tockner, Malard \& Ward, 2000; Ward \& Tockner, 2001). As flow slows, turbidity decreases somewhat, water levels stabilise, and benthic algae can become re-established. Waterholes were not studied under flood or high flow in this study, but these periods set the stage for the post-flow conditions that follow.

Post-flow/initial disconnection-Photic zone depth is a very good predictor of benthic GPP in both rivers under post-flow conditions, suggesting that light availability is the dominant controlling factor. Both rivers are similar under post-flow conditions with respect to water chemistry, but metabolism and photic depth have diverged, with greater values in 
Cooper waterholes. GPP/R is about 1 and $\mathrm{R}$ is tightly linked to GPP in Cooper Creek, while the benthic zone of Warrego waterholes is heterotrophic and the relationship between $\mathrm{R}$ and GPP is weak. This suggests the autotrophic component of the benthic biofilm is better established in Cooper waterholes compared to those in the Warrego, a trend that continues into dry conditions.

The May 2003 trip to four Warrego waterholes was an exception to the general patterns observed, with much higher values of photic zone depth, GPP and GPP/R than the other Warrego post-flow and dry trips. It appears that flow events in February/March and/or March/April contributed water of relatively lower turbidity, resulting in those four waterholes having characteristics very similar to post-flow Cooper Creek waterholes. Additionally, the proportion of fish abundance represented by introduced benthivorous carp was lower in May 2003 than the other three trips $(1 \pm 0.4 \%$, compared to a range of $10 \pm 5 \%$ to $24 \pm 6 \%$ for the other 3 trips; data from Balcombe et al., 2006), which may also influence turbidity and benthic biofilm development (see below). This suggests that regional processes which determined flow paths and quality of water delivered to the channels continue to influence benthic production into the post-flow period. Variability in turbidity of flows from event to event can not be fully characterised with only two post-flow sampling trips in each catchment, but data suggest that there is higher variability in the Warrego River compared to the Cooper Creek. A useful area of future investigation would be characterising variability in flow event turbidity and relating this to different hydrologic pathways to determine under what circumstances and how frequently post-flow turbidity is similar in the two catchments.

Dry/extended disconnection-As drying continues, local scale influences will increase in importance relative to catchment processes. Waterhole to waterhole variability should increase as local physical factors, such as orientation relative to dominant wind direction (fetch) and water depth, influence turbidity. Evaporation decreases water volume and 
concentrates solutes (Hamilton et al., 2005), as well as potentially increasing the relative density of fish by reducing the volume of aquatic habitat (Stanley, Fisher \& Grimm, 1997). Decreasing water depths increase the potential for re-suspension, as do higher spring wind speeds (September-October 20\% greater than April-May for Cooper Creek (Windorah, Queensland) and 25\% greater for the Warrego River (Cunnamulla, Queensland), Australian Bureau of Meteorology). Nutrient concentrations and turbidity therefore increase in both rivers in response to the contraction of aquatic habitat.

While trends in water chemistry are similar, the two catchments show very different patterns of benthic metabolism during drying. Waterholes in the Cooper Creek catchment become even more distinctive relative to Warrego waterholes and show higher withincatchment variability. Cooper Creek benthic GPP increases despite greater turbidity, and GPP/R increases and the littoral zone becomes strongly autotrophic. The greater day length and associated higher irradiance in spring versus autumn (mean $11 \mathrm{~h}$ daylight across all April/May trips versus mean $12.7 \mathrm{~h}$ across Sept/Oct trips, Australian Bureau of Meteorology) and more stable water levels (Walker et al., 1995; Bunn et al., 2006b) may contribute to this increase in GPP. In contrast, waterholes in the Warrego River do not exhibit an increase in GPP, GPP/R ratios are less than one, and waterholes have low values and low variability for GPP, R and photic depth. Similar to post-flow conditions, the relationship between GPP and $\mathrm{R}$ is strong in Cooper but not in Warrego waterholes. While the durations of no flow were similar between the two rivers during the study period, Cooper Creek can have much longer dry spells than the Warrego River. High rates of benthic GPP measured by Bunn et al. (2003) in some of the same Cooper Creek waterholes after a long dry spell (more than five years since a flood and 2 years since significant flow) suggest that duration of no-flow periods may also influence autotrophic biofilm establishment. 
Weaker relationships between photic depth and GPP during dry compared to postflow conditions were observed in both rivers, but the mechanisms responsible differed. The lack of relationship seen in Warrego waterholes during the dry period was likely due to the very low variability in photic depth and poorly established biofilm. In contrast, benthic algae were well developed in Cooper Creek waterholes, as shown by high values of GPP and GPP:R, but the lack of relationship with photic depth may be due to increased importance of biotic factors such as light attenuation within the biofilm (Losee \& Wetzel, 1983) and other consequences of cycles of biofilm accrual and sloughing successional processes within the biofilm, such as self-shading (Biggs, 1996).

\section{Factors influencing differences between Cooper Creek and the Warrego River}

Differences in rates of benthic metabolism and GPP:R ratio between the two rivers suggest that the autotrophic component of benthic biofilm is less well established in Warrego waterholes compared to Cooper Creek. Development and production of algal biofilms are controlled by levels of resources such as nutrients and light, the influence of grazing and disturbances such as mechanical damage (Biggs, 1996). Warrego waterholes have somewhat lower nutrient concentrations compared to Cooper waterholes, but this is unlikely to be the dominant factor because both rivers have adequate concentrations to suggest that nutrients are not limiting primary production (nutrient concentrations greater than the ANZECC \& ARMCANZ (2000) trigger values of 100 ug $\mathrm{P} \mathrm{L}^{-1}$ for TP and 1000 ug $\mathrm{N} \mathrm{L}^{-1}$ for TN for lowland rivers, south-central Australia). Additionally, positive relationships between GPP and nutrient concentrations were not observed. Light is more likely to be an important factor, and Warrego waterholes did, on average, have higher turbidity and lower photic zone depths than Cooper waterholes. For the one Warrego trip with a greater mean waterhole photic zone depth, GPP and GPP:R were also greater. Despite similar values for both rivers, however, 
the Cooper dry trips had 3-4 times greater GPP at the low end of the photic depth range. Therefore, it is unlikely that differences in photic zone depths are the only explanation for lower GPP in the Warrego waterholes. Two potential factors are 1) differences in bank slopes and 2) the presence of introduced carp in the Warrego River.

Steeper banks in Warrego waterholes may result in greater physical disturbance of benthic biofilm and therefore lower GPP and GPP:R values. Desiccation or greater submergence associated with changes in water levels, as well as wave action, are potential mechanisms of physical disturbance in the littoral zone (Lowe, 1996; Burns \& Walker, 2000) that are influenced by slope. With substantially steeper bank slopes for Warrego compared to Cooper waterholes (mean slopes of $19.0 \pm 2.4$ and $12.1 \pm 1.5$, respectively), the physical action of waves may result in greater disturbance of shallow benthic habitats.

Benthivorous introduced carp (Cyprinus carpio L.) present in the Warrego River and not Cooper Creek may also lead to greater disturbance of benthic biofilm. Carp and other cyprinids are known to bioturbate benthic sediments (Ten Winkel \& Davids, 1985; Lammens \& Hoogenboezem, 1991; Robertson, Healey \& King, 1997) and increase water column turbidity (Roberts et al., 1995; King, Robertson \& Healey, 1997) through their feeding activities. Similarly, feeding by native detritivorous fish has been suggested as an important control on benthic algal biomass in floodplain lakes in South America (Montoya et al., 2006; Winemiller et al., 2006). Frequent sediment disturbance in combination with high turbidity, which also may in part be due to the activities of carp, may strongly limit the development of the autotrophic component of benthic biofilm in Warrego waterholes.

Influence of hydrology on benthic production compared to other systems

While the flow variability of dryland rivers like the Cooper Creek and Warrego River is extreme compared to other rivers worldwide, cycles of expansion and contraction of 
aquatic habitat are characteristic of a range of aquatic ecosystems and have a strong influence on ecosystem functioning (Stanley et al., 1997; Tockner et al., 2000; Ward \& Tockner, 2001). Tockner et al. (2000) describe how regional processes at the catchment scale and local processes at the floodplain scale interact to influence spatial heterogeneity in floodplain rivers. The relative importance of regional and local processes varies from river to river, but also varies within a river over time due to changes in flow and associated expansion or contraction of aquatic habitat.

The contribution of different water sources and their degree of connectivity change with flow, influencing both the extent of aquatic habitat and the water quality, which in turn affect ecosystem processes like primary production (Stanley et al., 1997; Tockner et al., 2000). Changes in algal biomass and production with changes in flow have been studied in several floodplain rivers, including the Danube (Austria, Tockner et al., 1999), the Roseg River (Switzerland, Uehlinger, Zah \& Bürgi, 1998) and the Cinaruco River (Venezuela, Cotner et al., 2006; Montoya et al., 2006). Highest levels of primary production tend to be during low flows/low water levels, but for different reasons among rivers. Cinaruco and Danube floodplain water bodies have clear water, with water column primary production influenced by nutrient availability and water residence time. Annual floods dilute dissolved nutrient concentrations and increase water velocity in the Cinaruco River, serving to decrease water column production in floodplain lakes (Cotner et al., 2006). The highest algal productivity and biomass are associated with the low-water phase in which both nutrient concentrations and water residence time are higher (Cotner et al., 2006; Montoya et al., 2006). In the Danube floodplain, water column chlorophyll is also greatest under conditions of high nutrients and high residence times, but these conditions occur under mean water levels (Tockner et al., 1999). Mean water levels are associated with seepage of nutrient-rich 
groundwater, which alleviates the nutrient limitation that occurred in the floodplain water bodies at the lowest water levels.

In contrast to these two systems, periods of maximum production in the glacial Roseg River are controlled by light availability and substrate disturbance (Uehlinger et al., 1998). The Roseg River experiences maximum expansion in summer, during glacial melt (Ward \& Tockner, 2001). During this time, turbid water and bed load movement limit benthic algal biomass (Uehlinger et al., 1998). Higher algal biomass occurs in association with clear water conditions during the maximum contraction phases in spring and autumn.

The Cooper Creek and Warrego River might be expected to be similar to each other with respect to hydrology and algal dynamics, particularly in comparison to the rivers described above: glacial, tropical lowland and temperate lowland. However, conditions of maximum benthic production in the Cooper Creek are found under dry conditions, when water levels are stable and biofilms are mature and strongly autotrophic. Maximum benthic production in the Warrego River only occurs occasionally, when flows bring in low turbidity water. Benthic algal biofilm is poorly developed in Warrego waterholes at most times, and production is consistently low. If the turbidity of the source water filling waterholes is important for controlling post-flow production in both rivers, then processes within each waterhole have a more dominant role in influencing production during the dry, or maximum contraction. Similar to the Roseg River, turbidity exerts a strong influence on primary production under some hydrologic conditions. The two dryland rivers also share some similarities with the Cinaruco and Danube in that higher nutrient concentrations are found during low water conditions. However, consistently high levels of turbidity mean that primary production in the Cooper Creek and Warrego River does not respond to increases in nutrients, in contrast to the strong response seen in the Cinaruco and Danube. 
Fish abundance and benthic production

A link between benthic production and fish abundance at the broad catchment scale was suggested by higher values for both in Cooper Creek compared to the Warrego River. A significant positive relationship was observed between fish abundance and benthic GPP when all sampling times and sites were considered. This pattern, however, was not mirrored within catchments for all individual trips. The relationship was only significant for the post-flow trip to each catchment, not the dry trips. Stronger post-flow relationships are counter to what was expected since fish populations were presumed to become more strongly food-limited as time since major flow increased (Arthington et al., 2005; Balcombe et al., 2006). This suggests that factors other than food limitation are more important under dry conditions.

Previous work in Cooper waterholes indicated that benthic algal carbon is important to fish biomass (Bunn et al. 2003), but benthic primary production does not seem to be the main factor driving fish catches of individual waterholes in either catchment during the dry period. Physical habitat availability or deteriorating water quality may be more important controls on the populations as waterholes dry down (Arthington et al., 2005; Balcombe et al., 2006). Alternatively, there may be substantial lags between changes in benthic production and changes in fish abundance, particularly because most of the fish species are generalist carnivores (Balcombe et al., 2005) and therefore the link with algae involves at least one intermediate trophic level.

No-flow conditions during the 'bust' phase appear to be more of a 'bust' in the Warrego River compared to Cooper Creek waterholes, at least with respect to benthic primary production. The autotrophic component of benthic biofilm in Cooper Creek is more productive and appears to be better developed than that in the Warrego River, particularly after extended periods of no flow. Despite differences in benthic primary production, both rivers exhibited similar patterns in the shifting importance of regional versus local processes 
with changing hydrologic conditions. Regional processes appeared to exert more influence on ecosystem functioning during periods of flow, while local processes became most important when the rivers contracted to isolated waterholes under no-flow conditions. Changes in the scale of processes influencing rivers during cycles of expansion and contraction are key to the general model of floodplain river functioning proposed by Tockner et al. (2000) to expand the flood pulse concept from tropical to temperate regions. Patterns observed in the Cooper Creek and Warrego River suggest that the general landscape approach of Tockner et al. (2000) may also be applicable to the study of dryland rivers, despite the extremely variable hydrology of these systems.

\section{Acknowledgements}

The authors thank the landowners for access to their properties and the members of the Dryland Refugium team that contributed to the field work for this study, in particular Jo Clapcott and Sam Capon. Waterhole dimensions were provided by Martin Thoms and Louisa Davis. Wade Hadwen, Stephen Balcombe, Courtney Henderson, Joanne Burton, Kate Smolders, Cliff Dahm and two anonymous reviewers provided comments that substantially improved the manuscript. This study contributes to the Dryland River Refugia Project funded by the Cooperative Research Centre for Freshwater Ecology, Canberra. 


\section{References}

ANZECC \& ARMCANZ (2000) An introduction to the Australian and New Zealand guidelines for fresh and marine water quality, Australian and New Zealand Environment and Conservation Council and Agriculture and Resource Management Council of Australia and New Zealand, Canberra.

Arthington, A.H., Balcombe, S.R., Wilson, G.A., Thoms, M.C. \& Marshall, J. (2005) Spatial and temporal variation in fish-assemblage structure in isolated waterholes during the 2001 dry season of an arid-zone floodplain river, Cooper Creek, Australia. Marine and Freshwater Research, 56, 25-35.

Bailey, V. (2001) Western Streams Water Quality Monitoring Project, Queensland Department of Natural Resources and Mines, Brisbane, Australia.

Balcombe, S.R., Arthington, A.H., Foster, N.D., Thoms, M.C., Wilson, G.G. \& Bunn, S.E. (2006) Fish assemblages of an Australian dryland river: abundance, assemblage structure and recruitment patterns in the Warrego River, MurrayDarling Basin. Marine and Freshwater Research, 57, 619-633.

Balcombe, S.R., Bunn, S.E., McKenzie-Smith, F.J. \& Davies, P.M. (2005) Variability of fish diets between dry and flood periods in an arid zone floodplain river. Journal of Fish Biology, 67, 1552-1567.

Bender, M., Grande, K., Johnson, K., Marra, J., William, P.J.L., Sieburth, J., Pilson, M., Langdon, C., Hitchcock, G., Orchardo, J., Hunt, C., Donaghay, P. \& Heinemann, K. (1987) A comparison of four methods for determining planktonic community production. Limnology and Oceanography, 32, 10851098. 
Biggs, B.J.F. (1996) Patterns in benthic algae of streams. In: Algal Ecology: Freshwater Benthic Ecosystems. (Eds R.J. Stevenson, M.L. Bothwell \& R.L. Lowe), pp. 31-56. Academic Press, San Diego.

Bott, T.L., Brock, J.T., Cushing, C.E., Gregory, S.V., King, D. \& Petersen, R.C. (1978) A comparison of methods for measuring primary productivity and community respiration in streams. Hydrobiologia, 60, 3-12.

Bunn, S.E., Balcombe, S.R., Davies, P.M., Fellows, C.S. \& McKenzie-Smith, F.J. (2006a) Aquatic productivity and food webs of desert river ecosystems. In: Ecology of Desert Rivers. (Ed R.T. Kingsford), pp. 76-99. Cambridge University Press, New York.

Bunn, S.E., Davies, P.M. \& Winning, M. (2003) Sources of organic carbon supporting the food web of an arid zone floodplain river. Freshwater Biology, 48, 619-635.

Bunn, S.E., Thoms, M.C., Hamilton, S.K. \& Capon, S.J. (2006b) Flow variability in dryland rivers: boom, bust and the bits in between. River Research and Applications, 22, 179-186.

Burford, M.A., Cook, A.J., Fellows, C.S., Balcombe, S.R. \& Bunn, S.E. (in press) Sources of carbon fuelling production in an arid floodplain river. Marine and Freshwater Research.

Burns, A. \& Walker, K.F. (2000) Effects of water level regulation on algal biofilms in the River Murray, South Australia. Regulated Rivers-Research \& Management, 16, 433-444.

Clarke, K.R. \& Gorley, R.N. (2001) PRIMER v5: User Manual/Tutorial, PRIMER E, Plymouth. 
Cotner, J.B., Montoya, J.V., Roelke, D.L. \& Winemiller, K.O. (2006) Seasonally variable riverine production in the Venezuelan llanos. Journal of the North American Benthological Society, 25, 171-184.

Davies, B.R., Thoms, M.C., Walker, K.F., O'Keefe, J.H. \& Gore, J.A. (1994) Dryland rivers: their ecology, conservation and management. In: The Rivers Handbook. (Eds P. Calow \& G.E. Petts), pp. 484-511. Blackwell Scientific, Oxford.

Davis, L., Thoms, M.C., Fellows, C. \& Bunn, S. (2002) Physical and ecological associations in dryland refugia: waterholes of the Cooper Creek, Australia. In: The Structure, Function and Management Implications of Fluvial Sedimentary Systems. (Eds F.J. Dyer, M.C. Thoms \& J.M. Olley), pp. 77-84. Publ. no. 276. IAHS Press, Wallingford.

Fellows, C.S., Clapcott, J.E., Udy, J.W., Bunn, S.E., Harch, B.D., Smith, M.J. \& Davies, P.M. (2006) Benthic metabolism as an indicator of stream ecosystem health. Hydrobiologia, 572, 71-87.

Fellows, C.S., Wos, M.L., Pollard, P.C. \& Bunn, S.E. (2007) Ecosystem metabolism in a dryland river waterhole. Marine and Freshwater Research, 58, 250-262.

Fisher, S.G., Gray, L.J., Grimm, N.B. \& Busch, D.E. (1982) Temporal succession in a desert stream ecosystem following flash flooding. Ecological Monographs, 52, 93-110.

Hamilton, S.K., Bunn, S.E., Thoms, M.C. \& Marshall, J.C. (2005) Persistence of aquatic refugia between flow pulses in a dryland river system (Cooper Creek, Australia). Limnology and Oceanography, 50, 743-754.

Hart, B., Grace, M., Oliver, R. \& Rees, C. (1995) Nutrient cycling and algal blooms in the Darling River. In: Researching the Barwon-Darling: Proceedings of the Bourke Conference, New South Wales. (Eds M.C. Thoms, A. Gordon \& W. 
Tatnell), pp. 63-74. Cooperative Research Centre for Freshwater Ecology, Canberra.

King, A.J., Robertson, A.I. \& Healey, M.R. (1997) Experimental manipulations of the biomass of introduced carp (Cyprinus carpio) in billabongs. 1. Impacts on water-column properties. Marine and Freshwater Research, 48, 435-443.

Kingsford, R.T., Curtin, A.L. \& Porter, J. (1999) Water flows on Cooper Creek in arid Australia determine 'boom' and 'bust' periods for waterbirds. Biological Conservation, 88, 231-248.

Kingsford, R.T. \& Thomas, R.F. (1995) The Macquarie Marshes in arid Australia and their waterbirds - a 50-year history of decline. Environmental Management, 19, 867-878.

Kingsford, R.T. \& Thompson, J.R. (2006) Desert or dryland rivers of the world: an introduction. In: The Ecology of Desert Rivers. (Ed R.T. Kingsford), pp. 3-10. Cambridge University Press, New York.

Knighton, A.D. \& Nanson, G.C. (1994) Waterholes and their significance in the anastomosing channel system of Cooper Creek, Australia. Geomorphology, 9, 311-324.

Lambert, W. (1984) The measurement of respiration. In: A Manual on Methods for the Assessment of Secondary Productivity in Fresh Waters. (Eds J.A. Downing \& F.H. Rigler), pp. 413-468. Blackwell Scientific Publications, Oxford.

Lammens, E.H.R.R. \& Hoogenboezem, W. (1991) Diets and feeding behaviour. In: Cyprinid Fishes: Systematics, Biology and Exploitation. (Eds I.J. Winfield \& J.S. Nelson), pp. 353-376. Chapman and Hall, London. 
Losee, R.F. \& Wetzel, R.G. (1983) Selective light attenuation by the periphyton complex. In: Periphyton of Freshwater Ecosystems. (Ed R.G. Wetzel). Dr. W. Junk Publishers, The Hague.

Lowe, R.L. (1996) Periphyton patterns in lakes. In: Algal Ecology: Freshwater Benthic Ecosystems. (Eds R.J. Stevenson, M.L. Bothwell \& R.L. Lowe), pp. 57-76. Academic Press, San Diego.

Marshall, J.C., Sheldon, F., Thoms, M. \& Choy, S. (2006) The macroinvertebrate fauna of an Australian dryland river: spatial and temporal patterns and environmental relationships. Marine and Freshwater Research, 57, 61-74.

McGregor, G.B., Marshall, J.C. \& Thoms, M.C. (2006) Spatial and temporal variation in algal-assemblage structure in isolated dryland river waterholes, Cooper Creek and Warrego River, Australia. Marine and Freshwater Research, 57, 453-466.

Minshall, G.W. (1978) Autotrophy in stream ecosystems. BioScience, 28, 767-770.

Montoya, J.V., Roelke, D.L., Winemiller, K.O., Cotner, J.B. \& Snider, J.A. (2006) Hydrological seasonality and benthic algal biomass in a Neotropical floodplain river. Journal of the North American Benthological Society, 25, 157-170.

Mulholland, P.J., Fellows, C.S., Tank, J.L., Grimm, N.B., Webster, J.R., Hamilton, S.K., Marti, E., Ashkenas, L., Bowden, W.B., Dodds, W.K., McDowell, W.H., Paul, M.J. \& Peterson, B.J. (2001) Inter-biome comparison of factors controlling stream metabolism. Freshwater Biology, 46, 1503-1517.

Peres-Neto, P.R., Jackson, D.A. \& Somers, K.M. (2003) Giving meaningful interpretation to ordination axes: assessing loading significance in Principal Components Analysis. Ecology, 84, 2347-2363. 
119 Puckridge, J.T., Sheldon, F., Walker, K.F. \& Boulton, A.J. (1998) Flow variability and the ecology of large rivers. Marine and Freshwater Research, 49, 55-72.

121 Puckridge, J.T., Walker, K.F. \& Costelloe, J.F. (2000) Hydrological persistence and

122 the ecology of dryland rivers. Regulated Rivers-Research \& Management, 16, 385-402.

Roberts, J., Chick, A., Oswald, L. \& Thompson, P. (1995) Effect of carp, Cyprinus carpio L, an exotic benthivorous fish, on aquatic plants and water quality in experimental ponds. Marine and Freshwater Research, 46, 1171-1180.

Robertson, A.I., Healey, M.R. \& King, A.J. (1997) Experimental manipulations of the biomass of introduced carp (Cyprinus carpio) in billabongs. 2. Impacts on benthic properties and processes. Marine and Freshwater Research, 48, 445454.

Sheldon, F., Boulton, A.J. \& Puckridge, J.T. (2002) Conservation value of variable connectivity: aquatic invertebrate assemblages of channel and floodplain habitats of a central Australian arid-zone river, Cooper Creek. Biological Conservation, 103, 13-31.

Stanley, E.H., Fisher, S.G. \& Grimm, N.B. (1997) Ecosystem expansion and contraction in streams. BioScience, 47, 427-435.

Ten Winkel, E.H. \& Davids, C. (1985) Bioturbation by cyprinid fish affecting the food availability for predatory water mites. Oecologia, 67, 218-219.

Tockner, K., Malard, F. \& Ward, J.V. (2000) An extension of the flood pulse concept. Hydrological Processes, 14, 2861-2883.

Tockner, K., Pennetzdorfer, D., Reiner, N., Schiemer, F. \& Ward, J.V. (1999) Hydrological connectivity, and the exchange of organic matter and nutrients in 
a dynamic river-floodplain system (Danube, Austria). Freshwater Biology, 41, 521-535.

145

146

147

148

149

150

151

152

153

154

155

156

157

158

159

160

161

162

163

164
Uehlinger, U., Zah, R. \& Bürgi, H. (1998) The Val Roseg project: temporal and spatial patterns of benthic algae in an Alpine stream ecosystem influenced by glacier runoff. International Association of Hydrological Sciences Publication, 248, 419-434.

Vadeboncoeur, Y. \& Steinman, A.D. (2002) Periphyton function in lake ecosystems. The Scientific World Journal, 2, 1449-1468.

Walker, K.F., Sheldon, F. \& Puckridge, J.T. (1995) A perspective on dryland river ecosystems. Regulated Rivers-Research \& Management, 11, 85-104.

Ward, J.V. \& Tockner, K. (2001) Biodiversity: towards a unifying theme for river ecology. Freshwater Biology, 46, 807-819.

Wetzel, R.G. \& Likens, G.E. (1991) Limnological Analyses, Springer-Verlag.

Winemiller, K.O., Montoya, J.V., Roelke, D.L., Layman, C.A. \& Cotner, J.B. (2006) Seasonally varying impact of detritivorous fishes on the benthic ecology of a tropical floodplain river. Journal of the North American Benthological Society, $25,250-262$.

Young, W.J. \& Kingsford, R.T. (2006) Flow variability in large unregulated dryland rivers. In: Ecology of Desert Rivers. (Ed R.T. Kingsford), pp. 11-46. Cambridge University Press, New York. 
Table 1. Location and morphological characteristics of waterholes. Values are for bankfull conditions with the exception of mean slope, which is for the segment of measured bank cross sections typically intersected by the waterline during low flow and no flow conditions. QNRW =

Queensland Department of Natural Resources and Water. Dimensions of the waterholes are based on a combination of field surveys of waterhole cross sections and a long section and remotely sensed imagery (Davis et al. 2002). (-- = data not available)

\begin{tabular}{|c|c|c|c|c|c|c|c|c|c|}
\hline River & Waterhole & Group & South latitude & East longitude & $\begin{array}{l}\text { QNRW } \\
\text { Site No. }\end{array}$ & Area $\left(\mathrm{km}^{2}\right)$ & $\begin{array}{l}\text { Perimeter } \\
(\mathbf{k m})\end{array}$ & $\begin{array}{c}\text { Length } \\
(\mathbf{k m})\end{array}$ & $\begin{array}{l}\text { Volume } \\
\left(10^{3} \mathrm{~m}^{3}\right)\end{array}$ \\
\hline \multirow[t]{15}{*}{ Cooper } & Murken & Windorah & $25^{\circ} 25^{\prime} 46.6^{\prime \prime}$ & $142^{\circ} 43^{\prime} 57.9^{\prime \prime}$ & 0031004 & 1.305 & 253.6 & 9.5 & 1,305 \\
\hline & Mayfield & Windorah & $25^{\circ} 26^{\prime} 11.5^{\prime \prime}$ & $142^{\circ} 43^{\prime} 37.3^{\prime \prime}$ & 0031005 & 0.076 & 22.7 & 1.5 & 76 \\
\hline & Glen Murken & Windorah & $25^{\circ} 26^{\prime} 52.1^{\prime \prime}$ & $142^{\circ} 40^{\prime} 43.1^{\prime \prime}$ & 0031006 & 0.202 & 88.8 & 3.4 & 202 \\
\hline & Shed & Windorah & 252' 41.6" & $142^{\circ} 49^{\prime} 39.0^{\prime \prime}$ & 0031007 & 0.546 & 186.6 & 5.9 & 546 \\
\hline & One Mile & Springfield & $25^{\circ} 50^{\prime} 42.0^{\prime \prime}$ & $143^{\circ} 03^{\prime} 07.2^{\prime \prime}$ & 0031008 & 0.116 & 59.6 & 2.2 & 116 \\
\hline & Homestead & Springfield & $25^{\circ} 48^{\prime} 27.8^{\prime \prime}$ & $143^{\circ} 02^{\prime} 36.2^{\prime \prime}$ & 0031009 & 1.203 & 437.2 & 11.4 & 1,203 \\
\hline & Warrannee & Springfield & $25^{\circ} 54^{\prime} 30.7^{\prime \prime}$ & $143^{\circ} 05^{\prime} 23.6^{\prime \prime}$ & 0031010 & 0.310 & 96.0 & 3.7 & 310 \\
\hline & Tanbar & Tanbar & $25^{\circ} 50^{\prime} 13.3^{\prime \prime}$ & $141^{\circ} 55^{\prime} 00.3^{\prime \prime}$ & 0031011 & 1.773 & 909.9 & 18.6 & 1,773 \\
\hline & Yorakah & Tanbar & $25^{\circ} 57^{\prime} 31.3^{\prime \prime}$ & $141^{\circ} 52^{\prime} 41.9^{\prime \prime}$ & 0031012 & 0.127 & 39.4 & 1.7 & 127 \\
\hline & Yappi & Tanbar & $25^{\circ} 48^{\prime} 58.3^{\prime \prime}$ & $142^{\circ} 0141.5^{\prime \prime}$ & 0031013 & 0.234 & 203.0 & 6.6 & 234 \\
\hline & Yalungah & Tanbar & 2551' 13.6" & $141^{\circ} 58^{\prime} 25.2^{\prime \prime}$ & 0031014 & 0.379 & 88.0 & 2.9 & 379 \\
\hline & Waterloo & Noonbah & $24^{\circ} 13^{\prime} 38.2^{\prime \prime}$ & $143^{\circ} 17^{\prime} 23.3^{\prime \prime}$ & 0032022 & 0.638 & 159.6 & 5.8 & 638 \\
\hline & Bottom & Noonbah & $24^{\circ} 16^{\prime} 31.5^{\prime \prime}$ & $143^{\circ} 18^{\prime} 08.2^{\prime \prime}$ & 0032023 & 0.084 & 35.0 & 1.8 & 84 \\
\hline & Тор & Noonbah & $24^{\circ} 11^{\prime} 02.6^{\prime \prime}$ & $143^{\circ} 21^{\prime} 05.6^{\prime \prime}$ & 0032024 & 0.547 & 153.8 & 5.6 & 547 \\
\hline & Pelican & Noonbah & $24^{\circ} 13^{\prime} 35.0^{\prime \prime}$ & $143^{\circ} 20^{\prime} 06.1^{\prime \prime}$ & 0032025 & 0.059 & 21.2 & 1.2 & 59 \\
\hline \multirow[t]{15}{*}{ Warrego } & Quilberry & Quilberry & $27^{\circ} 04^{\prime} 49.5^{\prime \prime}$ & $145^{\circ} 55^{\prime} 23.3^{\prime \prime}$ & 4232014 & 0.426 & 147.4 & 5.7 & 426 \\
\hline & Clear & Quilberry & $27^{\circ} 04^{\prime} 28.2^{\prime \prime}$ & $145^{\circ} 57^{\prime} 27.0^{\prime \prime}$ & 4232015 & 0.344 & 54.6 & 2.7 & 344 \\
\hline & Stanford Park Waterhole & Quilberry & $26^{\circ} 54^{\prime} 23.8^{\prime \prime}$ & $146^{\circ} 02^{\prime} 00.0^{\prime \prime}$ & 4232016 & 0.426 & 146.1 & 4.9 & 426 \\
\hline & Stanford Park Lagoon & Quilberry & $26^{\circ} 55^{\prime} 24.4^{\prime \prime}$ & $146^{\circ} 02^{\prime} 13.8^{\prime \prime}$ & 4232017 & 0.086 & 20.3 & 1.1 & 86 \\
\hline & Glencoe & Glencoe & $28^{\circ} 12^{\prime} 18.4^{\prime \prime}$ & $145^{\circ} 42^{\prime} 52.0^{\prime \prime}$ & 4232018 & 0.306 & 117.9 & 4.3 & 306 \\
\hline & Woggannorah & Glencoe & $28^{\circ} 19^{\prime} 43.6^{\prime \prime}$ & $145^{\circ} 41^{\prime} 42.7^{\prime \prime}$ & 4232019 & 0.438 & 122.3 & 6.1 & 438 \\
\hline & Rocky & Glencoe & $28^{\circ} 17^{\prime} 05.9^{\prime \prime}$ & $145^{\circ} 38^{\prime} 43.7^{\prime \prime}$ & 4232020 & 0.036 & 29.4 & 1.4 & 36 \\
\hline & Kay & Glencoe & $28^{\circ} 19^{\prime} 12.6^{\prime \prime}$ & $145^{\circ} 43^{\prime} 38.7^{\prime \prime}$ & 4232021 & 0.027 & 3.2 & 0.5 & 27 \\
\hline & Binya & Binya & 2850'05.6" & $145^{\circ} 32^{\prime} 40.6^{\prime \prime}$ & 4232022 & 0.366 & 172.2 & 5.8 & 366 \\
\hline & Red & Binya & $28^{\circ} 47^{\prime} 17.8^{\prime \prime}$ & $145^{\circ} 37^{\prime} 49.3^{\prime \prime}$ & 4232023 & 0.061 & 30.8 & 1.8 & 61 \\
\hline & Mirage Plains & Binya & $28^{\circ} 38^{\prime} 32.2^{\prime \prime}$ & $145^{\circ} 36^{\prime} 16.1^{\prime \prime}$ & 4232024 & 0.103 & 93.9 & 3.7 & 103 \\
\hline & Tinnenburra & Binya & $28^{\circ} 43^{\prime} 58.5^{\prime \prime}$ & $145^{\circ} 33^{\prime} 00.7^{\prime \prime}$ & 4232025 & 0.080 & 53.3 & 2.3 & 80 \\
\hline & Noorama & Thurulgoona & $28^{\circ} 42^{\prime} 10.5^{\prime \prime}$ & $146^{\circ} 14^{\prime} 04.6^{\prime \prime}$ & 4232026 & 0.361 & 258.6 & 6.9 & 361 \\
\hline & Thurulgoona Homestead & Thurulgoona & $28^{\circ} 43^{\prime} 15.7^{\prime \prime}$ & $145^{\circ} 56^{\prime} 09.3^{\prime \prime}$ & 4232027 & 0.361 & 315.6 & 11.5 & 361 \\
\hline & Thurulgoona & Thurulgoona & $28^{\circ} 46^{\prime} 10.8^{\prime \prime}$ & $145^{\circ} 58^{\prime} 36.5^{\prime \prime}$ & 4232028 & 0.236 & 106.8 & 4.6 & 236 \\
\hline
\end{tabular}


Table 1. (Continued).

\begin{tabular}{|c|c|c|c|c|}
\hline River & Waterhole & $\begin{array}{c}\text { Fetch } \\
\text { (m) }\end{array}$ & $\begin{array}{c}\text { Mean } \\
\text { depth (m) }\end{array}$ & $\begin{array}{c}\text { Mean slope } \\
\left({ }^{\circ}\right)\end{array}$ \\
\hline \multirow[t]{15}{*}{ Cooper } & Murken & 1,410 & 5.1 & 6.3 \\
\hline & Mayfield & 429 & 3.4 & 14.4 \\
\hline & Glen Murken & 1,470 & 2.3 & 11.0 \\
\hline & Shed & 1,079 & 2.9 & 9.8 \\
\hline & One Mile & 335 & 2.0 & 11.3 \\
\hline & Homestead & 2,158 & 2.8 & 10.6 \\
\hline & Warrannee & 1,811 & 3.2 & 6.9 \\
\hline & Tanbar & 550 & 1.9 & 10.3 \\
\hline & Yorakah & 82 & 3.2 & 20.6 \\
\hline & Yappi & 444 & 1.2 & 9.5 \\
\hline & Yalungah & 202 & 4.3 & 3.1 \\
\hline & Waterloo & 1,016 & 4.0 & 22.9 \\
\hline & Bottom & 233 & 2.4 & - \\
\hline & Top & 498 & 3.6 & 13.7 \\
\hline & Pelican & 80 & 2.8 & 18.7 \\
\hline \multirow[t]{15}{*}{ Warrego } & Quilberry & 310 & 2.9 & 16.3 \\
\hline & Clear & 377 & 6.3 & 15.7 \\
\hline & Stanford Park Waterhole & 297 & 2.9 & 24.2 \\
\hline & Stanford Park Lagoon & 230 & 4.2 & 11.6 \\
\hline & Glencoe & 980 & 2.6 & 24.4 \\
\hline & Woggannorah & 262 & 3.6 & 18.3 \\
\hline & Rocky & 657 & 1.2 & 10.1 \\
\hline & Kay & 151 & 8.6 & 36.8 \\
\hline & Binya & 2,051 & 2.1 & 16.5 \\
\hline & Red & 203 & 2.0 & 37.2 \\
\hline & Mirage Plains & 587 & 1.1 & 19.6 \\
\hline & Tinnenburra & 217 & 1.5 & 18.3 \\
\hline & Noorama & 1,746 & 1.4 & -- \\
\hline & Thurulgoona Homestead & 3,009 & 1.1 & 8.3 \\
\hline & Thurulgoona & 2,157 & 2.2 & 8.8 \\
\hline
\end{tabular}


Table 2. Description of sampling trips. Time since flow ceased is based on a reading of 0 for the combined discharges recorded at the Barcoo

River at Retreat (GS 003301B) and Thompson River at Stonehenge (GS 003203A) gauges (Cooper Creek) or the Wyandra gauge on the Warrego River (GS 423204A). Time since flood ceased is based on a cutoff of 40,000 ML $\mathrm{d}^{-1}$ for Cooper Creek and 50,000 ML $\mathrm{d}^{-1}$ for the Warrego River. Water temperature is the mean of all waterholes sampled for mean temperature over a 24 hr period. Hours of daylight were determined from sunrise and sunset times from the Australian Bureau of Meteorology.

\begin{tabular}{|c|c|c|c|c|c|c|c|}
\hline River & $\begin{array}{c}\text { \# of } \\
\text { waterholes } \\
\text { sampled }\end{array}$ & Dates & Hydrologic status & $\begin{array}{c}\text { Time since } \\
\text { flow ceased } \\
\text { (months) }\end{array}$ & $\begin{array}{c}\text { Time since } \\
\text { flood ceased } \\
\text { (months) }\end{array}$ & $\begin{array}{c}\text { Mean water } \\
\text { temperature } \\
\left({ }^{\circ} \mathrm{C}\right)\end{array}$ & $\begin{array}{l}\text { Hours of } \\
\text { daylight }\end{array}$ \\
\hline \multirow[t]{4}{*}{ Cooper } & 15 & 20-29 April 2001 & post-flow & 0 & 3 & $20.9 \pm 0.4$ & 11.3 \\
\hline & 15 & 19-27 Sept 2001 & dry & 2 & 8 & $21.8 \pm 0.3$ & 12.9 \\
\hline & 4 & 12-13 Oct 2002 & dry & 6 & 9 & $21.6 \pm 0.2$ & 12.6 \\
\hline & 4 & 13-15 May 2003 & post-flow & 0 & 2 & $20.4 \pm 0.3$ & 10.9 \\
\hline \multirow[t]{4}{*}{ Warrego } & 15 & 16-23 Oct 2001 & dry & 2 & 11 & $19.3 \pm 0.4$ & 12.9 \\
\hline & 15 & 23-30 April 2002 & post-flow & 0 & 3 & $20.5 \pm 0.3$ & 11.1 \\
\hline & 4 & 9-11 Oct 2002 & dry & 6 & 9 & $18.7 \pm 0.6$ & 12.6 \\
\hline & 4 & 17-19 May 2003 & post-flow & 0 & 3 & $19.3 \pm 0.4$ & 10.7 \\
\hline
\end{tabular}


Table 3. Results of principal component analysis for benthic metabolism and water chemistry. Loadings for individual variables are given in parentheses.

\begin{tabular}{lllll}
\hline PC & Eigenvalue & \%Variation & $\begin{array}{l}\text { Cumulative } \\
\text { \% Variation }\end{array}$ & $\begin{array}{l}\text { Variables with coefficients of 0.5 or } \\
\text { greater }\end{array}$ \\
\hline 1 & 3.15 & 45.1 & 45.1 & $\begin{array}{l}\log \text { TN (-0.516), log TP (-0.518), } \\
\log \text { nitrate-N (-0.494) }\end{array}$ \\
2 & 2.20 & 31.4 & 76.5 & $\begin{array}{l}\log \text { R (-0.578), log GPP (-0.597), } \\
\log \text { photic depth (-0.497) }\end{array}$ \\
3 & 0.65 & 9.4 & 85.9 & log conductivity (-0.897) \\
\hline
\end{tabular}


Table 4. Results of regression analyses ( $\mathrm{r}^{2}$ values) examining factors influencing mean waterhole values of benthic metabolism and fish abundance across all trips $(\mathrm{n}=$ 76), each river separately $(n=38)$, and individual full spatial trips $(n=15)$.

Significant relationships and the level of significance are indicated by $0.05=*, 0.01=$ $* *, 0.001=* * *$, and $\leq 0.0001=* * * *$.

\begin{tabular}{llllllll}
\hline & all trips & $\begin{array}{c}\text { Cooper } \\
\text { all trips }\end{array}$ & $\begin{array}{c}\text { Warrego } \\
\text { all trips }\end{array}$ & $\begin{array}{c}\text { Cooper } \\
\text { post-flow } \\
\text { April 01 }\end{array}$ & $\begin{array}{c}\text { Cooper } \\
\text { dry } \\
\text { Sept 01 }\end{array}$ & $\begin{array}{c}\text { Warrego } \\
\text { post-flow } \\
\text { April 02 }\end{array}$ & $\begin{array}{c}\text { Warrego } \\
\text { dry } \\
\text { Oct 01 }\end{array}$ \\
\hline \hline $\log$ R X log GPP & $0.43^{* * * *}$ & $0.67 * * * *$ & $0.18^{* *}$ & $0.78^{* * * *}$ & $0.68^{* * * *}$ & 0.26 & 0.23 \\
$\log$ GPP X log photic depth & $0.32^{* * * *}$ & $0.21^{* *}$ & $0.37 * * * *$ & $0.68^{* * *}$ & $0.36^{*}$ & $0.64^{* * *}$ & $0.40^{* *}$ \\
$\log$ GPP X log TN & 0.04 & 0.00 & 0.06 & 0.00 & 0.06 & 0.00 & $0.30^{*}$ \\
$\log$ GPP X log TP & 0.01 & 0.01 & $0.15^{*}$ & $0.30^{*}$ & 0.08 & 0.18 & $0.52^{* *}$ \\
$\log$ GPP X log nitrate-N & 0.02 & 0.00 & 0.10 & 0.22 & 0.05 & $0.34^{*}$ & 0.17 \\
$\log$ CPUE X log GPP & $0.27^{* * * *}$ & 0.00 & $0.32^{* * *}$ & $0.35^{*}$ & 0.06 & $0.41^{* *}$ & 0.16 \\
\hline
\end{tabular}




\section{Figure Legends}

Figure 1. Locations of waterholes sampled in the Cooper Creek and Warrego River catchments. Individual waterholes are indicated with circles.

Figure 2. Hydrographs for the sampling period for (A) Cooper Creek and (B) Warrego River. Cooper Creek discharge is the sum of the discharges recorded from gauges on the Barcoo River at Retreat and Thompson River at Stonehenge. Warrego River discharge is from the Wyandra gauge on the Warrego River. Sampling dates are represented with arrows.

Figure 3. PCA (PC1 and PC2, 76\% variation) of benthic metabolism and chemical and physical water characteristics across all waterholes and all trips. Symbols represent mean values and error bars represent one SE. (A) Mean values for all waterholes, all trips, for the two rivers. (B) Mean waterhole values for each full trip ( $n$ = 15). (C) Mean values for each trip for only the subset of 4 waterholes sampled on all trips. Smaller symbols indicate the second set of trips to each catchment. Loadings for individual variables are listed in Table 3.

Figure 4. Bivariate plots of mean waterhole values ( \pm SE) for benthic metabolism and chemical and physical water characteristics for the four full trips $(n=15$, panels A, C, and E) and for each trip for only the subset of 4 waterholes sampled on all trips ( $n=4$, panels B, D, and F). Smaller symbols in panels B, D, and F indicate the second set of trips to each catchment. 
Figure 5. Relationships between benthic GPP and light penetration for Cooper Creek (A) and the Warrego River (B). Results of linear regression analyses are shown for the full spatial trips to each catchment ( $n=15$ waterholes each). Each point represents a single waterhole (values for GPP are means of 4 benthic chambers).

Figure 6. Mean waterhole values ( $\pm \mathrm{SE}$ ) for fish abundance (catch per unit effort [CPUE]) and benthic GPP for (A) the four full trips ( $n=15)$ and (B) for each trip for only the subset of 4 waterholes sampled on all trips $(n=4)$. Smaller symbols in panel B indicate the second set of trips to each catchment.

Figure 7. Relationships between fish abundance and benthic GPP. Results of linear regression analyses are shown for (A) all trips to both rivers $(n=76)$ and the full spatial trips to each catchment ( $n=15$ waterholes each) for (B) Cooper Creek and the (C) Warrego River. Each point represents a single waterhole (values for GPP are means of 4 benthic chambers). 
Figure 1.

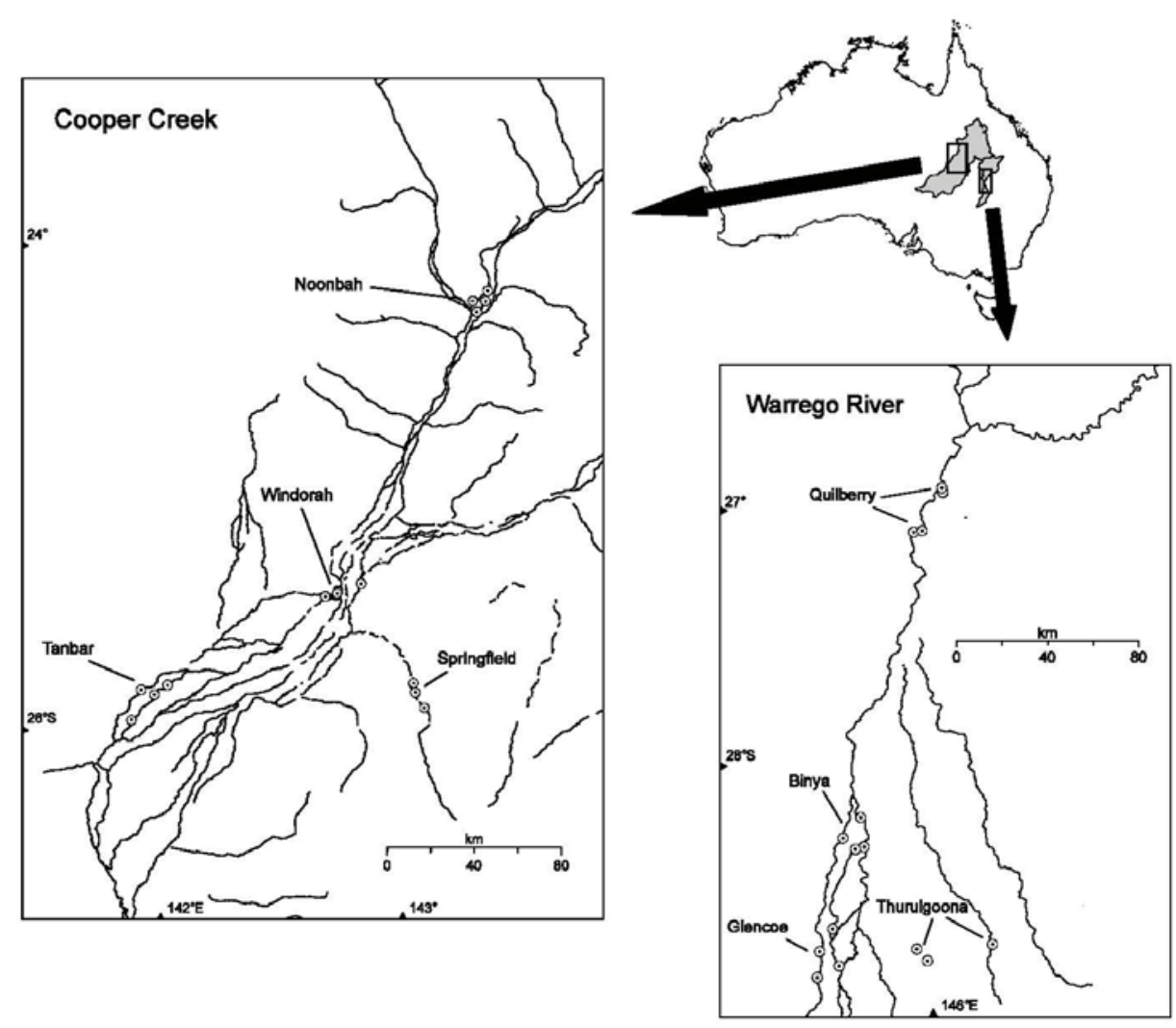


Figure 2
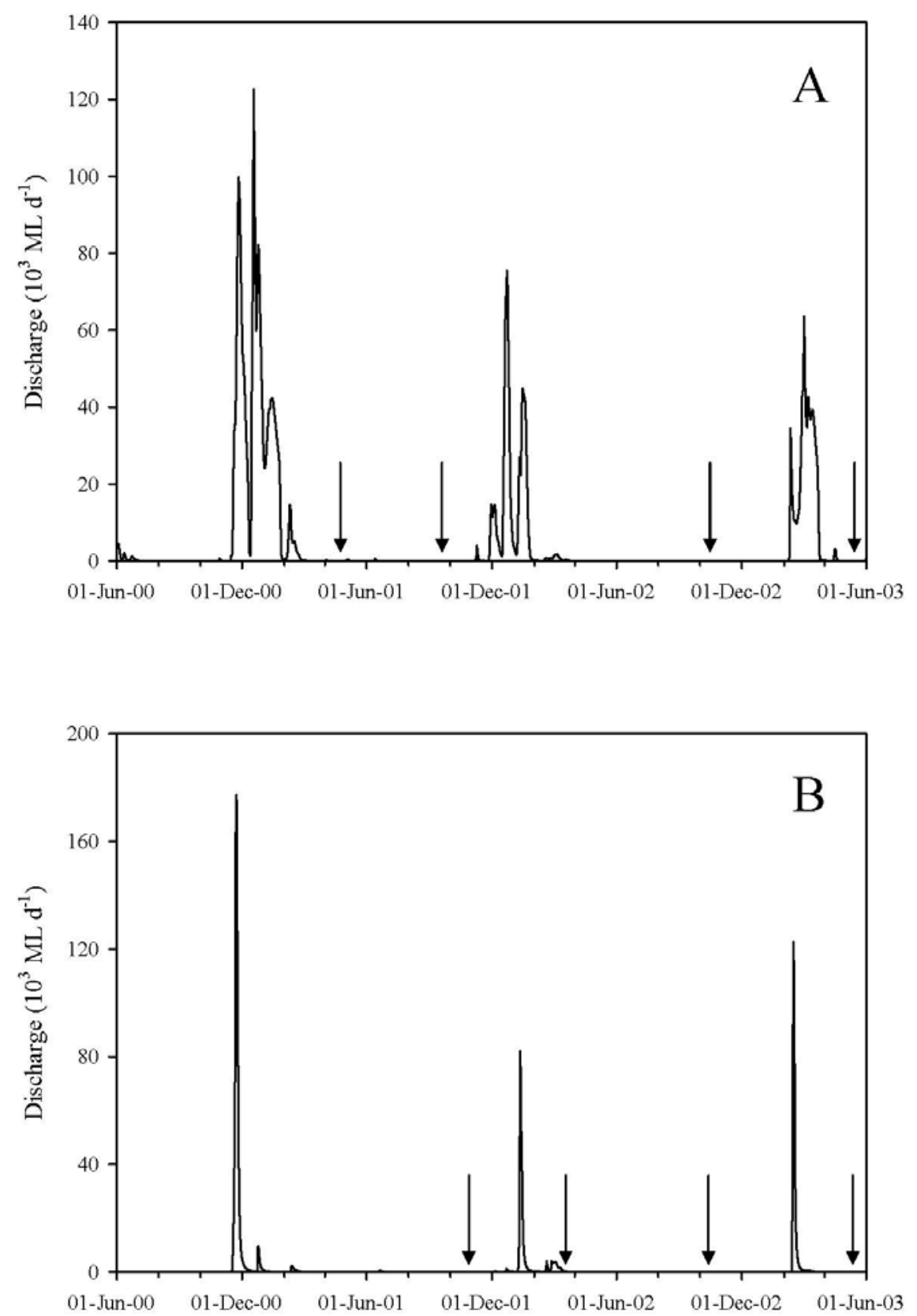
Figure 3
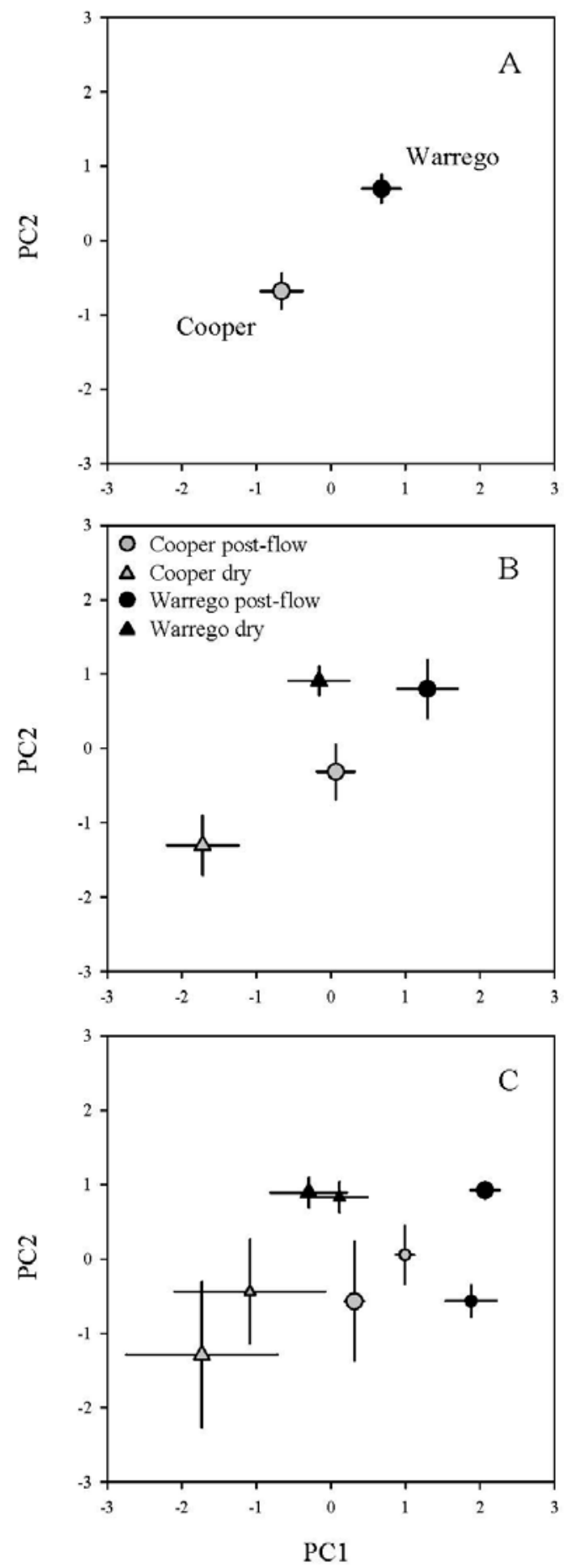
Figure 4
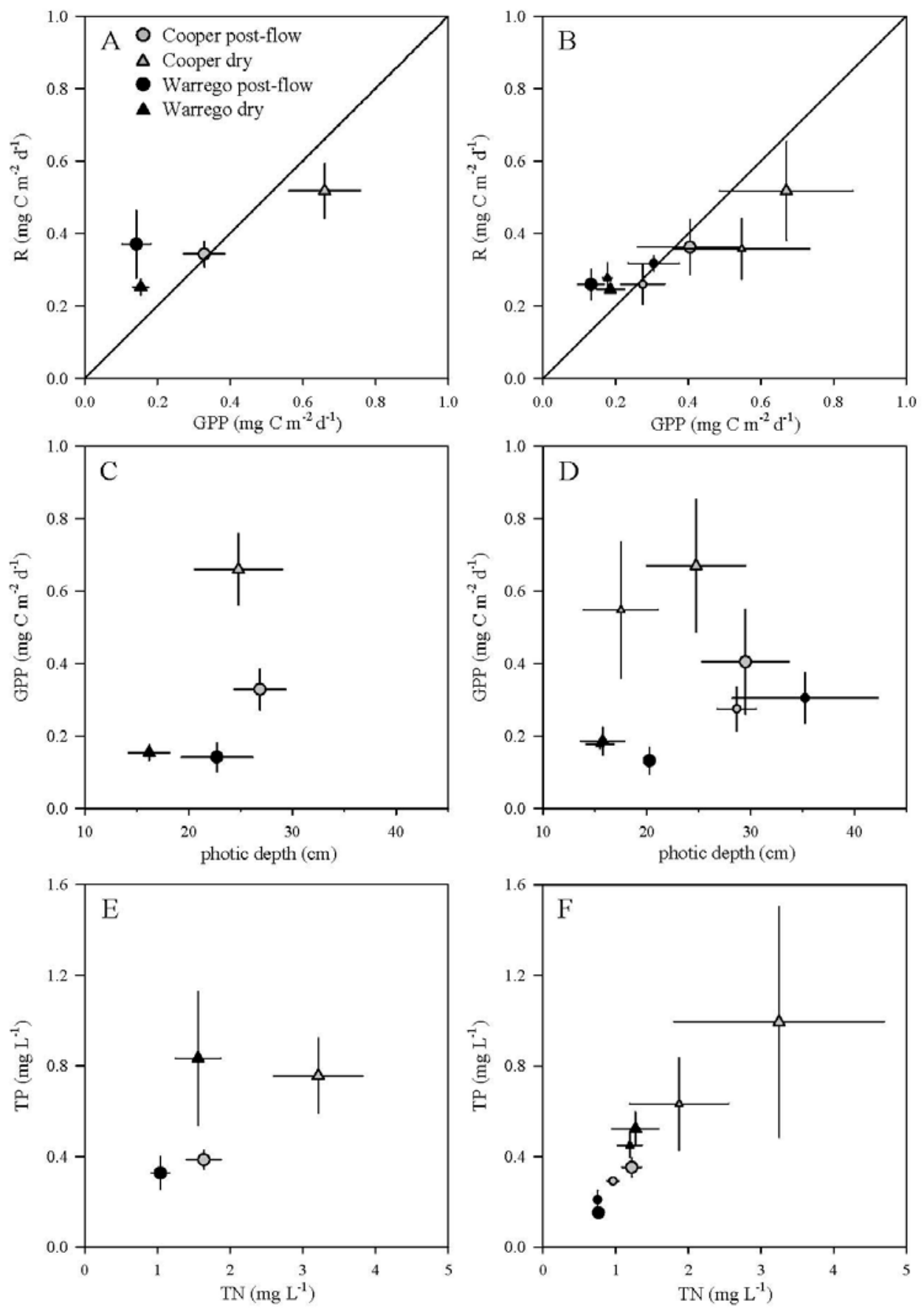
Figure 5
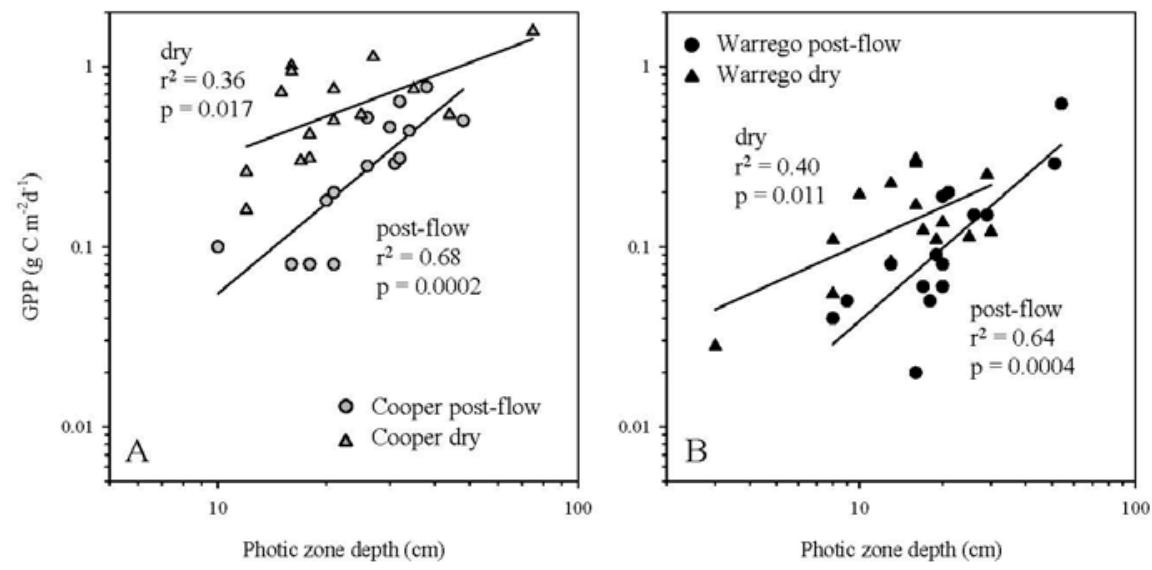
Figure 6
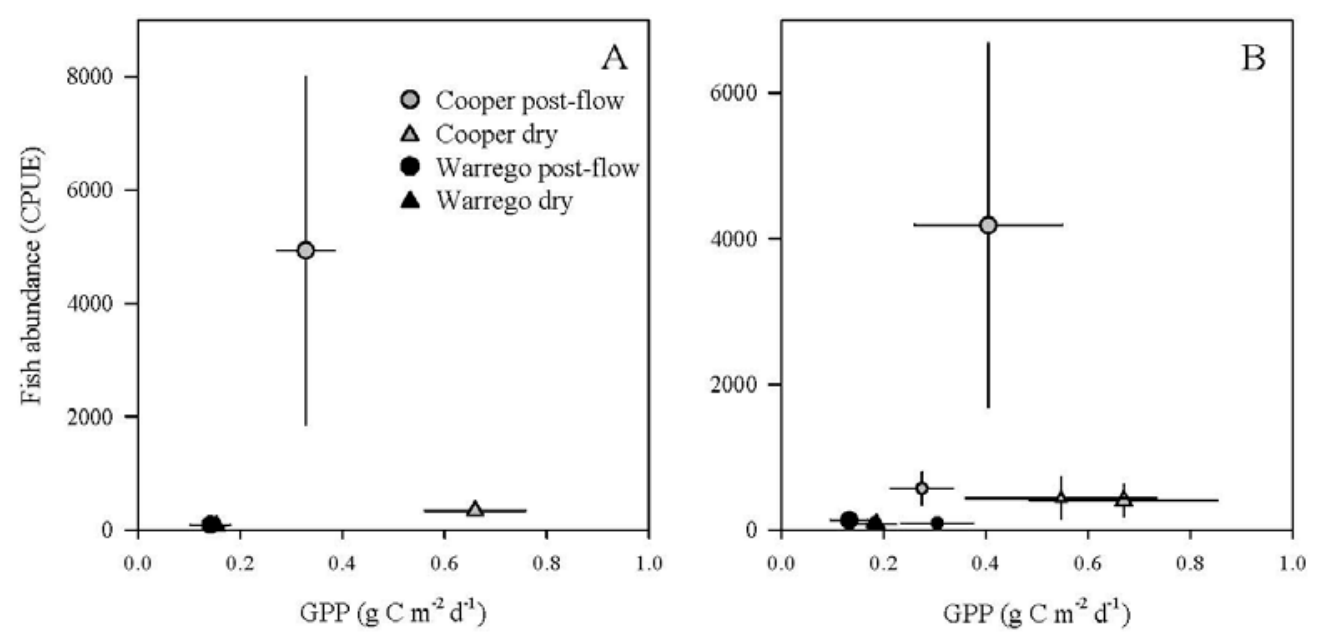
Figure 7
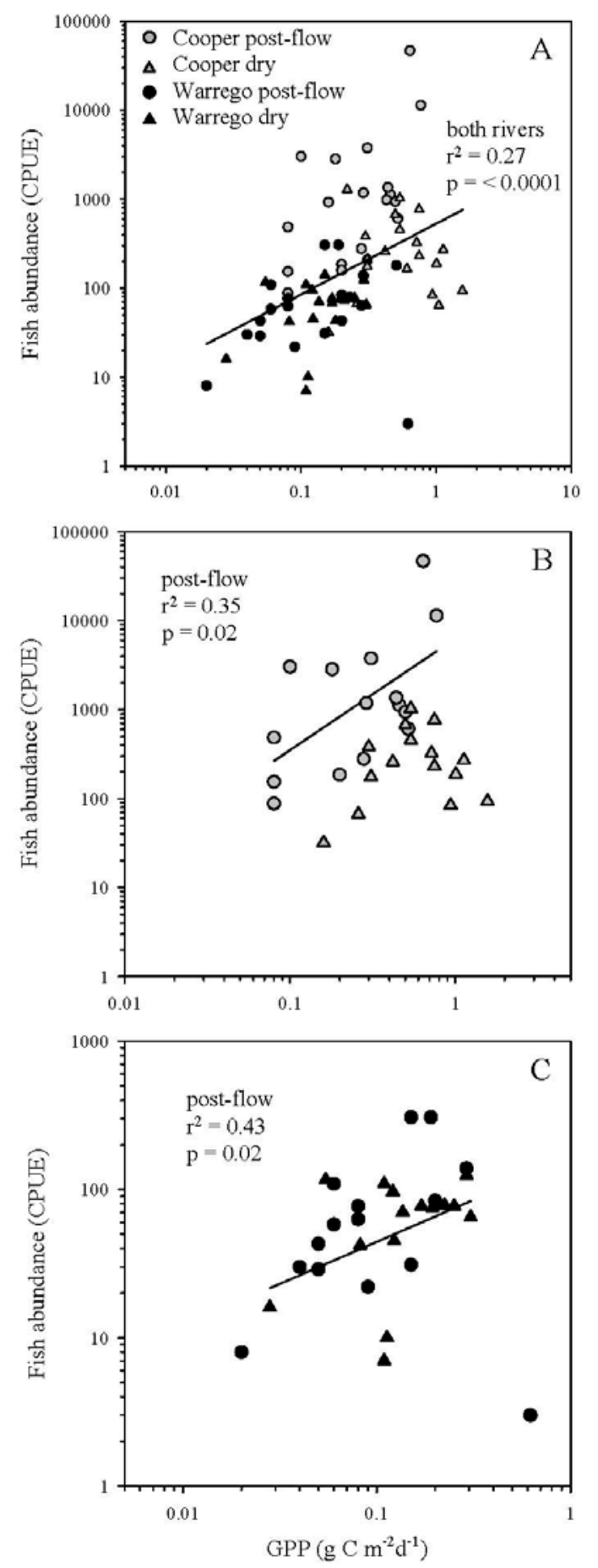